\title{
THE
}

\section{Financial crisis and the market efficiency in the Chinese equity markets}

Fang Chen

University of Rhode Island

Jeffrey E. Jarrett

University of Rhode Island, jejarrett133@outlook.com

Follow this and additional works at: https://digitalcommons.uri.edu/cba_facpubs

Terms of Use

All rights reserved under copyright.

\section{Citation/Publisher Attribution}

Fang Chen \& Jeffrey Jarrett, 2011. "Financial crisis and the market efficiency in the Chinese equity markets," Journal of the Asia Pacific Economy, Taylor \& Francis Journals, vol. 16(3), pages 456-463. Available at: https://doi.org/10.1080/13547860.2011.589632

This Article is brought to you for free and open access by the College of Business at DigitalCommons@URI. It has been accepted for inclusion in College of Business Faculty Publications by an authorized administrator of DigitalCommons@URI.For more information, please contact digitalcommons-group@uri.edu. 


\section{Financial crisis and the market efficiency in the Chinese equity markets}

\section{Fang Chen \& Jeffrey E. Jarrett}

To cite this article: Fang Chen \& Jeffrey E. Jarrett (2011) Financial crisis and the market efficiency in the Chinese equity markets, Journal of the Asia Pacific Economy, 16:3, 456-463, DOI: 10.1080/13547860.2011.589632

To link to this article: https://doi.org/10.1080/13547860.2011.589632

曲 Published online: 02 Aug 2011.

Submit your article to this journal $\widetilde{T}$

Џll Article views: 432

Q View related articles $\asymp$

4 Citing articles: 7 View citing articles 진 


\title{
Financial crisis and the market efficiency in the Chinese equity markets
}

\author{
Fang Chen ${ }^{\mathrm{a}}$ and Jeffrey E. Jarrett $\mathrm{t}^{\mathrm{b} *}$ \\ ${ }^{a}$ Department of Finance, University of Rhode Island, Kingston, Rhode Island, USA; ${ }^{b}$ Department of \\ Management Science and Finance, University of Rhode Island, Kingston, Rhode Island, USA
}

\begin{abstract}
We examine the behavior of the Chinese equity markets to determine whether the equity markets are efficient or not. A previously unexplored database provides the source for observing market behavior of the two principal equity markets in China. These markets have unique characteristics different from those in the more established markets in the United States, the United Kingdom and Japan, among others. In particular, we study the role of the financial crises. Our observations suggest that differences in statistical measures occurred before and after the financial crises. In addition, conclusions are drawn about the market efficiency of the Chinese equity markets that are based on well-known analytical methods. On the basis of the analysis, we observe that the equity markets of both exchanges were not efficient before the financial crisis and became efficient to some extent in terms of the weak-form efficiency markets hypothesis during the financial crisis. Finally, note that some changes in the Chinese financial markets occurred during and after the crises to alleviate the premium paid in Chinese markets relative to the same firms' share in the Hong Kong Stock Exchange.
\end{abstract}

Keywords: Chinese equity markets; variance ratio; variation; financial crisis; efficient markets

JEL classifications: G12, G14

\section{Introduction}

As a rapidly growing economy and experiencing large volatility in its equity markets, China attracts a great deal of worldwide attention. Chinese equity markets play active roles in their growth and are becoming a larger portion of the whole world's equity markets. There are two major equity exchanges in China: the Shanghai Stock Exchange (SHSE), established on 19 December 1990, and the Shenzhen Stock Exchange (SHSZ), established on 3 April 1991. Past research focusing on the market efficiency in these exchanges produced mixed results. Laurence et al. (1997) and Liu et al. (1997) by studying the Chinese market index claimed that the weak form of the efficient markets' hypothesis (see Fama 1991) prevailed in Chinese equity markets. Moreover, Chen et al. (2010) found the relatively weak predictability for Chinese stocks, although they did not interpret this as the evidence of an efficient Chinese market. In contrast, Moorkejee and Yu (1999) concluded that the Chinese market is inefficient when the parametric and non-parametric tests are conducted. Furthermore, Jarrett et al. (2009) indicated that there is little or no

\footnotetext{
*Corresponding author. Email: jejarrett@mail.uri.edu
} 
Granger (1969) causality between the equity markets and the Chinese macroeconomy. In addition, we should recognize that return predictability is often related to misreading of information by investors about the Chinese equity markets and to be misguided by 'irrational' preferences of decision makers. A number of studies in the Chinese equity markets have documented strong behavioral biases on the part of investors exhibited by overconfidence, disposition effects, bias and herd mentality (see Feng and Seasholes 2005, Shumway and $\mathrm{Wu} 2005$, Chen et al. 2007). Equity trading, in addition, is dominated by individual investors and not by institutional investors (Chen et al. 2007). During the Asian financial crisis, China was one of the few countries to rebound from the crisis. Its GDP growth was $11.4 \%$ in $2007,9 \%$ in 2008 and $8.7 \%$ in 2009 . However, no research has still been conducted on the impact of financial crisis on China's stock market efficiency.

Our research will compare the China's market efficiency before the financial crisis (2002-2006) and during the crisis (2007-2008). Also, because of the different characteristics of the Shanghai and Shenzhen stock exchanges, we will investigate the impact of the financial crisis on them respectively. We focus on A shares because of their small size and very limited trading activity in B shares.

\section{Data and methodology}

We obtain the Chinese stock market data from the Pacific-Basin Capital Markets Research Center (PACAP) and the PACAP-CCER China Database located at the University of Rhode Island $^{1}$ (Kingston, RI, USA). We analyze the daily data and monthly index data for class A shares trading in the Shanghai and Shenzhen stock exchanges. The index is constructed using both value-weighted and equal-weighted methods, respectively. The research contains the index data from January 2002 to December 2008. The purpose is to compare the market efficiency before the financial crisis (2002-2006) with that during the financial crisis (2007-2008). The final data sample has a total of 1692 observations of daily index and 84 observations of monthly index.

The normality of the distribution of returns has been questioned for a long time (Mandelbrot 1963, Fama 1965). Market efficiency is not affected by the normal assumption. However, the examination of the shape of the return distribution depicts a clear background of the Chinese stock market. Firstly, we examine the skewness, kurtosis and arithmetic mean, and median of daily and monthly returns for each of the four indexes. Secondly, we follow the method of Lo and MacKinlay $(1988,1999)$ for using the variance ratio to test the random walk model of market efficiency. This technique compares the spreads or variability of two sets of figures to determine whether the two sets of figures were drawn from the same population. Under the random walk hypothesis, a linear relationship exists between the increases in variance and the time interval. On the other hand, the variance in $q$-period is $q$ times of the variance of one period. The variance ratio in $q$-period is as follows:

$$
V R(q) \equiv \frac{\operatorname{Var}\left[r_{t}(q)\right]}{q \cdot \operatorname{Var}\left[r_{t}\right]},
$$

where $r_{t}$ is the natural logarithm of its gross return $\left(1+R_{t}\right)$, $\operatorname{Var}\left[r_{t}(q)\right]$ is the variance of the stock return over $q$-periods and $\operatorname{Var}\left[r_{t}\right]$ is the variance of the stock return in one period. The null hypothesis test of market efficiency using the variance ratio test is employed under two assumptions: $z(q)$ for homoscedasticity and $z^{*}(q)$ for heteroskedasticity. Here, $z(q)$ assumes an independent and identically distributed (IID) stock price. Let our sample contain $n q+1$ observations $\left\{p_{0}, p_{1}, \ldots, p_{n q}\right\}$, where $q$ is any integer greater than 1 . Under this asymptotic 
distribution assumption, the asymptotic distribution of the variance ratio is given by:

$$
z(q)=[V R(q)-1] / \sqrt{\{[2(2 q-1)(q-1)] / 3 q(n q)\}} \approx N(0,1) .
$$

Note that $z^{*}(q)$ allows more general assumption to be made of heteroskedasticity of the error term and is defined as follows:

$$
z^{*}(q)=[V R(q)-1] / \sqrt{\theta^{*}} \approx N(0,1)
$$

Here, $\theta^{*}$ is heteroskedasticity-consistent estimator and computed as follows:

$$
\theta^{*}(q)=\left(4 \sum_{k=1}^{q-1}\left(1-\frac{k}{q}\right)^{2} \delta_{k}^{*}\right) / n q
$$

where

$\delta_{k}=\left[n q \sum_{j=k+1}^{n q}\left(p_{j}-p_{j-1}-\mu\right)^{2}\left(p_{j-k}-p_{j-k-1}-\mu\right)^{2}\right] /\left[\sum_{j=1}^{n q}\left(p_{j}-p_{j-1}-\mu\right)^{2}\right]^{2}$.

\section{Empirical results}

Table 1 provides a summary of the Shanghai and Shenzhen equity markets or exchanges from 2002 to 2008 . The number of listed companies in both exchanges increased over time from 1206 in 2002 to 1576 in 2008. During this period, there were about 10\%-14\% more listed companies in the Shanghai Stock Exchange than in the Shenzhen Stock Exchange. In 2002, the number of listed companies was 705 in the Shanghai exchange and 501 in the Shenzhen exchange. In 2008, there were 851 listed companies in the Shanghai exchange and 725 in the Shenzhen exchange. The size of both markets in 2002 was 1171.09 million RMB and up and down since then. In 2008, it reached a peak of 4538.53 million RMB. Also, the market value of the Shanghai exchange grew each year compared

Table 1. China market overview.

\begin{tabular}{lccccccr}
\hline & \multicolumn{3}{c}{$N$} & & & \multicolumn{3}{c}{ Market value (RMB billions) } \\
\cline { 2 - 3 } \cline { 8 - 8 } Year & SHSE & SZSE & Total & & SHSE & SZSE & Total \\
\hline 2002 & 705 & 501 & 1206 & & 701.96 & 469.13 & 1171.09 \\
2003 & 772 & 494 & 1266 & & 781.98 & 450.78 & 1232.76 \\
2004 & 831 & 531 & 1362 & & 705.14 & 395.15 & 1100.29 \\
2005 & 829 & 536 & 1365 & & 649.61 & 344.46 & 994.07 \\
2006 & 835 & 582 & 1417 & & 1580.75 & 763.91 & 2344.66 \\
2007 & 852 & 664 & 1516 & 6257.58 & 2679.74 & 8937.32 \\
2008 & 851 & 725 & 1576 & & 3118.03 & 1240.50 & 4358.53 \\
\hline
\end{tabular}

Note: This table reports market characteristics of the Shanghai and Shenzhen Exchanges of China from 2002 to 2008. $N$ is the number of the listed firms. Market values are the closing prices multiplied by shares outstanding on the last trading day of each year. We use equal weight for the year-end cross-sectional averages for each exchange in each year. 
Table 2. Stock index return statistics.

\begin{tabular}{|c|c|c|c|c|c|c|c|c|}
\hline Sample period & $\begin{array}{c}\text { Sample } \\
\text { size }\end{array}$ & Mean & Median & $S D$ & Skew & Kurtosis & Min. & Max. \\
\hline \multicolumn{9}{|c|}{ Daily returns } \\
\hline & \multicolumn{8}{|c|}{ Shanghai A-share equal-weighted index } \\
\hline 2002:01:01-2006:12:31 & 1200 & 0.00021 & 0.0004 & 0.016 & 0.238 & 3.175 & -0.072 & 0.095 \\
\hline \multirow[t]{2}{*}{ 2007:01:01-2008:12:31 } & 488 & 0.00120 & 0.0059 & 0.030 & -0.542 & 0.715 & -0.088 & 0.096 \\
\hline & \multicolumn{8}{|c|}{ Shanghai A-share value-weighted index } \\
\hline 2002:01:01-2006:12:31 & 1204 & 0.00079 & 0.0007 & 0.014 & 0.544 & 4.111 & -0.066 & 0.095 \\
\hline \multirow[t]{2}{*}{ 2007:01:01-2008:12:31 } & 488 & 0.00095 & 0.0049 & 0.028 & -0.030 & 0.767 & -0.091 & 0.099 \\
\hline & \multicolumn{8}{|c|}{ Shenzhen A-share equal-weighted index } \\
\hline 2002:01:01-2006:12:31 & 1204 & 0.00015 & 0.0006 & 0.016 & 0.135 & 2.800 & -0.075 & 0.093 \\
\hline \multirow[t]{2}{*}{ 2007:01:01-2008:12:31 } & 488 & 0.00110 & 0.0054 & 0.031 & -0.580 & 0.842 & -0.089 & 0.097 \\
\hline & \multicolumn{8}{|c|}{ Shenzhen A-share value-weighted index } \\
\hline 2002:01:01-2006:12:31 & 1204 & 0.00076 & 0.0008 & 0.015 & 0.402 & 3.524 & -0.068 & 0.093 \\
\hline 2007:01:01-2008:12:31 & 488 & 0.00160 & 0.0046 & 0.030 & -0.396 & 0.740 & -0.089 & 0.099 \\
\hline \multicolumn{9}{|c|}{ Monthly returns } \\
\hline \multicolumn{9}{|c|}{ Shanghai A-share equal-weighted index } \\
\hline 2002:01:01-2006:12:31 & 60 & 0.00380 & 0.0012 & 0.079 & 1.074 & 2.878 & -0.127 & 0.319 \\
\hline 2007:01:01-2008:12:31 & 24 & -0.0301 & 0.0526 & 0.181 & 0.008 & -0.84 & -0.259 & 0.392 \\
\hline \multicolumn{9}{|c|}{ Shanghai A-share value-weighted index } \\
\hline 2002:01:01-2006:12:31 & 60 & 0.01841 & 0.0012 & 0.052 & 3.143 & 10.58 & -0.046 & 0.266 \\
\hline 2007:01:01-2008:12:31 & 24 & 0.36719 & 0.0408 & 1.679 & 4.831 & 23.54 & -0.258 & 8.218 \\
\hline \multicolumn{9}{|c|}{ Shenzhen A-share equal-weighted index } \\
\hline 2002:01:01-2006:12:31 & 60 & 0.00280 & -0.0057 & 0.083 & 0.988 & 2.559 & -0.142 & 0.326 \\
\hline 2007:01:01-2008:12:31 & 24 & 0.02827 & 0.0574 & 0.180 & -0.126 & -1.17 & -0.265 & 0.336 \\
\hline \multicolumn{9}{|c|}{ Shenzhen A-share value-weighted index } \\
\hline 2002:01:01-2006:12:31 & 60 & 0.0194 & 0.0016 & 0.054 & 3.469 & 12.47 & -0.052 & 0.308 \\
\hline 2007:01:01-2008:12:31 & 24 & 0.9313 & 0.0594 & 4.364 & 4.887 & 23.92 & -0.248 & 21.41 \\
\hline
\end{tabular}

to that of the Shenzhen exchange. In 2002, the market value of the Shanghai exchange was 701.96 million RMB compared to 469.13 million RMB of the Shenzhen exchange. In 2008, the market value of the Shanghai and Shenzhen exchanges was 3118.03 and 1240.53 million RMB, respectively. In summary, the Shanghai exchange had more listed companies and a larger market value than the Shenzhen exchange, although both exchanges witnessed an increasing trend over time.

Table 2 reports the statistical properties of daily and monthly returns for class A stock indexes on the Shanghai and Shenzhen exchanges. The statistics are divided into two sample periods: before the crisis (2002-2006) and during the crisis (2007-2008). First, the overall mean daily returns of both equal-weighted and value-weighted indexes of the Shanghai exchange were larger than those of the Shenzhen exchange before and during the crisis. For example, mean equal-weighted daily return of the Shanghai exchange before the crisis was $0.021 \%$, while it was $0.015 \%$ for the Shenzhen exchange in the same period. The only exception was the value-weighted index during crisis: $0.095 \%$ in the Shanghai exchange and $0.16 \%$ in the Shenzhen exchange. Second, the mean daily returns in both exchanges increased significantly during the crisis compared to the period before the crisis. For example, the mean equal-weighted daily returns of the Shanghai exchange increased almost five times from $0.021 \%$ before the crisis to $0.12 \%$ during the crisis, while those of the Shenzhen exchange increased more than six times from $0.015 \%$ to $0.11 \%$, respectively.

The standard deviations of daily returns are almost the same in both exchanges. For example, before the crisis, the standard deviation is 1.6 in the Shanghai exchange and 1.4 in the Shenzhen exchange. However, the standard deviation rose steeply during the crisis 
period for all four indexes of these exchanges. In the Shanghai exchange, the standard deviation of the equal-weighted daily returns before and during the crisis increased from 1.6 to 3.0, respectively, and from 1.4 to 2.8 in the Shenzhen exchange, respectively. The large increase in the standard deviation indicates a much higher level of volatility in the Chinese markets during the crisis. Therefore, the financial crisis had a huge impact on the stock index return statistics in both the exchanges.

Moreover, all four indexes show that the distributions of daily return in both exchanges are not normal before and during the crisis. The skewness measures are all positive before the crisis and become negative during the crisis. The asymmetrical distribution implies that there are more likely to be negative returns during the crisis. The change of the skewness is pronounced. For example, the skewness for equal-weighted index return in the Shanghai exchange is 0.238 before the crisis and -0.542 during the crisis. Similarly, the kurtosis measures are positive for each of the four indexes and represent a peaked or leptokurtic distribution. Note that the kurtosis fell sharply during the crisis. For example, the kurtosis of the equal-weighted index return in the Shanghai exchange is 3.173 before the crisis and 0.715 during the crisis.

Table 3 presents the results for the variance ratio for the daily stock index return using the equal-weighted and value-weighted methods, respectively, in both exchanges. The table also reports the $t$-statistics assuming homoscedasticity and heteroskedasticity. The lag length ranges from two to 16 days. Assuming homoscedasticity, before the crisis, we find that the equal-weighted index return of the Shanghai exchange is greater than 1 and significant at all lag lengths. Moreover, the variance ratio increases from 1.07 to 1.34 as the lag length increases from 2 to 16 . During the financial crisis, variance ratio is significantly larger than 1 only at lag lengths of eight and 16 days, although it is little higher than that before the crisis. The variance ratio is not significantly larger than 1 at lag lengths of two and four days. In other words, the autocorrelation of the equal-weighted index daily return is much weaker during the crisis. The result indicates that the equal-weighted daily index is more likely to follow the random walk and thus the market is more likely to be efficient during the financial crisis.

The value-weighted index daily return in the Shanghai exchange shows a similar pattern. The variance ratio is significantly greater than 1 for lag lengths of eight and 16 days. However, the autocorrelation at lag lengths 8 and 16 disappears during the financial crisis. Note that the $t$-statistics show similar results assuming heteroskedasticity.

Similarly, the variance ratio of the equal-weighted daily index return in the Shenzhen exchange is significantly greater than 1 before the crisis at all lags, but becomes non-significant at lag 2 assuming homoscedasticity and at lags 1 and 2 assuming heteroskedasticity. This result indicates a weak autocorrelation and stronger market efficiency during the crisis.

In summary, from the daily index return, we observe that equity market of both exchanges is not efficient before the financial crisis and becomes efficient to some extent in terms of weak-form efficiency during the financial crisis.

Table 4 reports the result of variance ratio for the monthly stock index return using equal-weighted and value-weighted methods, respectively, in both exchanges. In general, the variance ratio is larger than that of the daily index return in both exchanges due to the long interval of observation. In the Shanghai exchange, the variance ratio of the equalweighted index is significantly larger than 1 for lag lengths of 4-16 days assuming both homoscedasticity and heteroskedasticity before the financial crisis. However, the variance ratio is not significantly larger than 1 except at lag eight days during the crisis. In other words, assuming homoscedasticity and heteroskedasticity, the random walk null hypothesis cannot be rejected for most of the lag lengths during the crisis. Thus, the monthly equal-weighted index return is more likely to follow the random walk during the crisis. 
Table 3. Variance ratios for daily stock index return.

\begin{tabular}{|c|c|c|c|c|c|}
\hline \multirow[b]{2}{*}{ Sample period } & \multirow{2}{*}{$\begin{array}{l}\text { Number of } \\
\text { observation }\end{array}$} & \multicolumn{4}{|c|}{$\begin{array}{l}\text { Number } q \text { of base observations } \\
\text { aggregated to form variance ratio }\end{array}$} \\
\hline & & 2 & 4 & 8 & 16 \\
\hline \multicolumn{6}{|c|}{ Shanghai A-share equal-weighted index } \\
\hline 2002:01:01-2006:12:31 & 1203 & $\begin{array}{l}1.07 \\
(2.47)^{*} \\
\end{array}$ & $\begin{array}{c}1.14 \\
(2.62)^{*} \\
\end{array}$ & $\begin{array}{c}1.23 \\
(2.73)^{*} \\
\end{array}$ & $\begin{array}{c}1.34 \\
(2.63)^{*}\end{array}$ \\
\hline 2007:01:01-2008:12:31 & 487 & $\begin{array}{c}1.08 \\
(1.85) \\
{[1.57]}\end{array}$ & $\begin{array}{l}1.16 \\
(1.93) \\
{[1.69]}\end{array}$ & $\begin{array}{l}1.37 \\
(2.72)^{*} \\
{[2.46]^{*}}\end{array}$ & $\begin{array}{c}1.58 \\
(2.84)^{*} \\
{[2.67]^{*}}\end{array}$ \\
\hline \multicolumn{6}{|c|}{ Shanghai A-share value-weighted index } \\
\hline 2002:01:01-2006:12:31 & 1203 & $\begin{array}{c}1.04 \\
(1.25) \\
{[1.14]}\end{array}$ & $\begin{array}{c}1.09 \\
(1.69) \\
{[1.50]}\end{array}$ & $\begin{array}{c}1.17 \\
(1.99)^{*} \\
{[1.68]}\end{array}$ & $\begin{array}{c}1.32 \\
(2.47)^{*} \\
{[2.10]^{*}}\end{array}$ \\
\hline 2007:01:01-2008:12:31 & 487 & $\begin{array}{c}1.01 \\
(0.28) \\
{[0.25]}\end{array}$ & $\begin{array}{c}1.03 \\
(0.36) \\
{[0.33]}\end{array}$ & $\begin{array}{c}1.16 \\
(1.19) \\
{[1.13]}\end{array}$ & $\begin{array}{c}1.28 \\
(1.39) \\
{[1.34]}\end{array}$ \\
\hline \multicolumn{6}{|c|}{ Shenzhen A-share equal-weighted index } \\
\hline 2002:01:01-2006:12:31 & 1203 & $\begin{array}{l}1.08 \\
(2.90)^{*} \\
{[2.56]^{*}}\end{array}$ & $\begin{array}{c}1.17 \\
(3.15)^{*} \\
{[2.65]^{*}}\end{array}$ & $\begin{array}{c}1.28 \\
(3.23)^{*} \\
{[2.63]^{*}}\end{array}$ & $\begin{array}{c}1.37 \\
(2.91)^{*} \\
{[2.40]^{*}}\end{array}$ \\
\hline 2007:01:01-2008:12:31 & 487 & $\begin{array}{l}1.09 \\
(2.03)^{*} \\
{[1.71]}\end{array}$ & $\begin{array}{l}1.15 \\
(1.80) \\
{[1.57]}\end{array}$ & $\begin{array}{l}1.36 \\
(2.64)^{*} \\
{[2.39]^{*}}\end{array}$ & $\begin{array}{l}1.60 \\
(2.97)^{*} \\
{[2.79]^{*}}\end{array}$ \\
\hline \multicolumn{6}{|c|}{ Shenzhen A-share value-weighted index } \\
\hline 2002:01:01-2006:12:31 & 1203 & $\begin{array}{c}1.06 \\
(1.92) \\
{[1.76]}\end{array}$ & $\begin{array}{l}1.13 \\
(2.43)^{*} \\
{[2.12]^{*}}\end{array}$ & $\begin{array}{c}1.24 \\
(2.80)^{*} \\
{[2.34]^{*}}\end{array}$ & $\begin{array}{c}1.40 \\
(3.11)^{*} \\
{[2.61]^{*}}\end{array}$ \\
\hline 2007:01:01-2008:12:31 & 487 & $\begin{array}{c}1.07 \\
(1.51) \\
{[1.35]}\end{array}$ & $\begin{array}{c}1.10 \\
(1.18) \\
{[1.08]}\end{array}$ & $\begin{array}{l}1.28 \\
(2.06)^{*} \\
{[1.93]}\end{array}$ & $\begin{array}{c}1.47 \\
(2.31)^{*} \\
{[2.21]^{*}}\end{array}$ \\
\hline
\end{tabular}

Note: The standard normal test-statistics under homoscedasticity are within parentheses. The standard normal test-statistics under heteroscedasticity are within square brackets. Test-statistics marked with asterisks indicate that the corresponding variance ratios are statistically different from that at the $5 \%$ level of significance.

The monthly value-weighted index return of the Shanghai exchange shows a similar pattern. The variance ratio is significantly greater than 1 for all lag lengths. However, the autocorrelation at lag lengths one and 16 days disappears during the financial crisis. Again, note the similarity of results for the $t$-statistics assuming heteroskedasticity.

Similarly, assuming homoscedasticity and heteroskedasticity, the variance ratio of the equal-weighted monthly index return of the Shenzhen exchange is greater than 1 before the crisis at all lag lengths, but decreases at all lag lengths during the crisis except at lag length of one day. This indicates a weak autocorrelation but considerable market efficiency during the crisis.

\section{Summary and conclusion}

The result of the monthly index return confirms that equity markets of both exchanges are not efficient before the financial crisis and become efficient in terms of weak form of the efficient markets hypothesis to some extent during the financial crisis. The overall results 
Table 4. Variance ratios for monthly stock index return.

\begin{tabular}{|c|c|c|c|c|c|}
\hline \multirow[b]{2}{*}{ Sample period } & \multirow{2}{*}{$\begin{array}{l}\text { Number of } \\
\text { observation }\end{array}$} & \multicolumn{4}{|c|}{$\begin{array}{c}\text { Number } q \text { of base observations aggregated } \\
\text { to form variance ratio }\end{array}$} \\
\hline & & 2 & 4 & 8 & 16 \\
\hline \multicolumn{6}{|c|}{ Shanghai A-share equal-weighted index } \\
\hline 2002:01:01-2006:12:31 & 59 & $\begin{array}{c}1.21 \\
(1.56) \\
{[1.48]}\end{array}$ & $\begin{array}{l}1.61 \\
(2.40)^{*} \\
{[2.52]^{*}}\end{array}$ & $\begin{array}{l}2.56 \\
(3.76)^{*} \\
{[4.33]^{*}}\end{array}$ & $\begin{array}{l}4.78 \\
(5.63)^{*} \\
{[7.21]^{*}}\end{array}$ \\
\hline 2007:01:01-2008:12:31 & 23 & $\begin{array}{l}1.11 \\
(0.53) \\
{[0.67]}\end{array}$ & $\begin{array}{l}1.45 \\
(1.06) \\
{[1.31]}\end{array}$ & $\begin{array}{l}5.57 \\
(5.98)^{*} \\
{[8.3]^{*}}\end{array}$ & $\begin{array}{c}0.55 \\
(-0.26) \\
{[-0.58]}\end{array}$ \\
\hline \multicolumn{6}{|c|}{ Shanghai A-share value-weighted index } \\
\hline 2002:01:01-2006:12:31 & 59 & $\begin{array}{c}1.55 \\
(4.18)^{*} \\
{[2.05]^{*}}\end{array}$ & $\begin{array}{l}2.07 \\
(4.23)^{*} \\
{[2.49]^{*}}\end{array}$ & $\begin{array}{c}3.81 \\
(6.79)^{*} \\
{[2.07]^{*}}\end{array}$ & $\begin{array}{c}6.22 \\
(7.77)^{*} \\
{[4.23]^{*}}\end{array}$ \\
\hline 2007:01:01-2008:12:31 & 23 & $\begin{array}{l}1.32 \\
(1.49) \\
{[7.74]^{*}}\end{array}$ & $\begin{array}{c}2.34 \\
(3.13)^{*} \\
{[12.03]^{*}}\end{array}$ & $\begin{array}{c}5.07 \\
(5.33)^{*} \\
{[21.48]^{*}}\end{array}$ & $\begin{array}{c}0.48 \\
(-0.31) \\
{[-1.63]}\end{array}$ \\
\hline \multicolumn{6}{|c|}{ Shenzhen A-share equal-weighted index } \\
\hline 2002:01:01-2006:12:31 & 59 & $\begin{array}{c}1.17 \\
(1.25) \\
{[1.27]}\end{array}$ & $\begin{array}{l}1.51 \\
(2.01)^{*} \\
{[2.19]^{*}}\end{array}$ & $\begin{array}{l}2.34 \\
(3.24)^{*} \\
{[3.81]^{*}}\end{array}$ & $\begin{array}{c}4.36 \\
(5.00)^{*} \\
{[6.45]^{*}}\end{array}$ \\
\hline 2007:01:01-2008:12:31 & 23 & $\begin{array}{l}1.15 \\
(0.69) \\
{[0.85]}\end{array}$ & $\begin{array}{l}1.53 \\
(1.24) \\
{[1.47]}\end{array}$ & $\begin{array}{c}5.74 \\
(6.21)^{*} \\
{[8.40]^{*}}\end{array}$ & $\begin{array}{c}0.63 \\
(-0.22) \\
{[-0.48]}\end{array}$ \\
\hline \multicolumn{6}{|c|}{ Shenzhen A-share value-weighted index } \\
\hline 2002:01:01-2006:12:31 & 59 & $\begin{array}{c}1.60 \\
(4.52)^{*} \\
{[2.25]^{*}}\end{array}$ & $\begin{array}{l}2.26 \\
(4.99)^{*} \\
{[2.89]^{*}}\end{array}$ & $\begin{array}{l}4.25 \\
(7.84)^{*} \\
{[5.34]^{*}}\end{array}$ & $\begin{array}{l}7.18 \\
(9.21)^{*} \\
{[7.66]^{*}}\end{array}$ \\
\hline 2007:01:01-2008:12:31 & 23 & $\begin{array}{c}1.30 \\
(1.39) \\
{[11.78]^{*}}\end{array}$ & $\begin{array}{c}2.16 \\
(2.72)^{*} \\
{[16.80]^{*}}\end{array}$ & $\begin{array}{c}4.42 \\
(4.47)^{*} \\
{[24.55]^{*}}\end{array}$ & $\begin{array}{c}0.44 \\
(-0.34) \\
{[-2.21]^{*}}\end{array}$ \\
\hline
\end{tabular}

Note: The standard normal test-statistics under homoscedasticity are given in parentheses. The standard normal test-statistics under heteroscedasticity are given within square brackets. Test-statistics marked with asterisks indicate that the corresponding variance ratios are statistically different from that at the $5 \%$ level of significance.

suggest that an asset's price is more likely to reflect all information available about that asset during the financial crisis. Hence, if the economic 'bubble' is inflated, the Chinese equity markets appear more efficient than during the financial crisis. These conclusions are indicative of the period studied and the data collected and analyzed in this study.

One of the oddities of the Chinese equity markets is the premium that mainland investors pay for same shares listed on Chinese exchanges and traded in the Hong Kong Stock Exchange (HKE). The premium disappeared in the past year (The Economist 2010). The last time the prices on the mainland and HKE were the same was in 2006 when foreign fund managers flooded into the HKE looking for potential gains from severely low-priced offerings. In 2008 and 2009, prices in the mainland exchanges fell rapidly, making these exchanges the world's worst-performing markets. However, the prices of the same shares in the HKE fell at a much less rapid pace. Hence, some conclude that investors from outside China are more willing to believe China's growth story better than investors within the nation. 
Other explanations concerning the drop in prices in the Chinese markets include methods to liberalize the trading of the Chinese currency, the demand on the part of firms to list in China and the proposed plans by China to invest $\$ 586$ billion infrastructure and social welfare by the end of 2010 and into 2011. This stimulus package is similar to those implemented and proposed in Western nations to focus on housing, rural infrastructure, transportation, health and education, environment, disaster reconstruction, tax cuts and finance.

\section{Note}

1. The Pacific-Basin Capital Markets Research Center is located at the University of Rhode Island/ College of Business Administration/Ballentine Hall, Kingston, RI 02881, USA.

\section{References}

Chen, G., et al., 2007. Trading performance, disposition effect, overconfidence, representativeness bias, and experience of emerging market investors. Journal of behavioral decision making, 20 (4), 425-451.

Chen, X., et al., 2010. On the predictability of Chinese stock returns. Pacific-basin finance journal, 18 (4), 403-425.

Fama, E., 1965. The behavior of stock market prices. Journal of business of the University of Chicago, $38,34-105$.

Fama, E., 1991. Efficient capital markets: II. Journal of finance, 46, 1575-1617.

Feng, F. and Seasholes, M., 2005. Do investor sophistication and trading experience eliminate behavioral biases in financial markets? Review of finance, 9, 305-351.

Granger, C.W.J., 1969. Investigating causal relations by econometric models and cross-spectral methods. Econometrica, 37 (3), 424-438.

Jarrett, J.E., Pan, X., and Chen, S., 2009. Do the Chinese bourses (stock markets) predict economic growth? International journal of business and economics, 8 (3), 201-211.

Laurence, M., Cai, F., and Qian, S., 1997. Weak-form efficiency and causality tests in Chinese stock markets. Multinational finance journal, 1, 291-307.

Liu, X., Haiyan, S., and Romilly, P., 1997. Are Chinese stock markets efficient? 'A co-integration and causality analysis'. Applied economics letters, 4, 511-515.

Lo, A.W. and MacKinlay, A.C., 1988. The size and power of the variance ratio tests in finite samples: a Monte Carlo investigation. Journal of econometrics, 40, 203-238.

Lo, A.W. and MacKinlay, A.C., 1999. A random walk down Wall Street. Princeton, NJ: Princeton University Press.

Mandelbrot, B., 1963. The variation of certain speculative prices. Journal of business of the University of Chicago, 36, 394-419.

Moorkejee, R. and Yu, Q., 1999. An empirical analysis of the equity markets in China. Review of financial economics, 8 (1), 41-60.

Shumway, T. and Wu, G., 2005. Does disposition drive momentum? [online]. AFA 2006 Boston Meetings Paper. Available from: SSRN: http://ssrn.com/abstract=686901 [Accessed 15 March 2005].

The Economist, 2010. China's financial markets; premium puzzle; enthusiasm for Chinese companies abroad but not at home. The Economist, Hong Kong Online ed. Available from: www.economist. com/node/16646054 [Accessed 22 July 2010]. 